\title{
Pengaruh penambahan tepung sortgum dan bit root terhadap karakteristik flake
}

The effect of adding sorghum flour and root beet flour to the flake characteristics

\author{
Nur Fitri Hidayati ${ }^{1)}$, Muh. Aniar Hari Swasono ${ }^{1)^{*}}$ \\ ${ }^{1}$ Program Studi Ilmu dan Teknologi Pangan, Fakultas Pertanian, UniversitasYudharta Pasuruan \\ *Email korespondesi: aniarhari@yudharta.ac.id
}

Informasi Artikel:

Dikirim: 03/06/2021; disetujui: 25/07/2021; diterbitkan: 28/09/2021

\begin{abstract}
One of the potential dry land food plants developed in Indonesia is sorghum. Sorghum is a kind of grass crop and is still a family with rice, corn and wheat. The carbohydrate content in the seeds is quite high, so it can be consumed as staple food, along with the development of many innovations that are done to make this plant to be better known and in the community's favor, one of the processed sorghum is Flakes, Sorghum Flakes is a processed food based on sorghum with the addition of beetroot root, sugar, salt and water. This study aims to determine the effect of the addition of sorghum flour (30 $\mathrm{gr}$, $60 \mathrm{gr}, 90 \mathrm{gr})$ and beetroot flour $(5 \mathrm{gr}, 10 \mathrm{gr}, 15 \mathrm{gr})$ to the characteristics of Flakes, Organoleptic parameters were analyzed statistically using the Fridmen test while to find out the best treatment in the test Organoleptic tests were carried out on the effectiveness index test, the experimental design used the Completely Randomized Design (CRD) method with 2 factors and 3 repetitions. The best treatment is determined by the effectiveness index test with the calculation results show the best treatment is on S2B2 with a formulation of $60 \mathrm{gr}$ sorghum flour and $10 \mathrm{gr}$ beetroot flour
\end{abstract}

Keywords : Sorghum Flakes, Flakes characteristics, bit root, effectiveness test

\begin{abstract}
ABSTRAK
Salah satu tanaman pangan lahan kering yang potensial dikembangkan di Indonesia adalah sorgum. Sorgum adalah tanaman sejenis rumput-rumputan dan masih satu keluarga dengan padi, jagung, dan gandum.Kandungan karbohidrat dalam bijinya cukup tinggi, sehingga dapat dikonsumsi sebagai makanan pokok, seiring dengan perkembangan jaman banyak inovasi yang di lakukan untuk membuat tanaman ini agar lebih di kenal dan di gemari masyarakat ,salah satu olahan sorgum adalah Flakes, Flakes sorgum merupakan makanan olahan berbahan dasar sorgum dengan penambahan bit root, gula, garam dan air. Penelitian ini bertujuan mengetahui pengaruh penambahan tepung sorgum $(30 \mathrm{gr}, 60 \mathrm{gr}, 90 \mathrm{gr})$ dan tepung bit root (5 gr, 10gr, $15 \mathrm{gr}$ ) terhadap karakteristik Flakes, Parameter organoleptik dilakukan analisis statistik menggunakan uji Fridmen sedangkan untuk mengetahui perlakuan terbaik dalam uji organoleptik dilakukan uji indeks efektivitas, Rancangan percobaan menggunakan metode Rancangan Acak Lengkap (RAL) dengan 2 faktor dan 3 kali pengulangan. Perlakuan terbaik ditentukan dengan uji indeks efektivitas dengan Hasil perhitungan menunjukkan perlakuan terbaik terdapat pada S2B2 dengan formulasi 60gr tepung sorgum dan 10gr tepung bit root
\end{abstract}

Kata kunci : Flakes sorgum, karakteristik Flakes, bit root, uji efektifitas 


\section{PENDAHULUAN}

krisis pangan dan energi yang berdampak pada kenaikan harga pangan dan energi, sehingga negara-negara pengekspor pangan cenderung menahan produknya untuk dijadikan stok pangan. Mengingat kondisi global tersebut, maka Indonesia dituntut untuk terus meningkatkan ketahanan pangan agar mampu menyediakan pangan yang cukup bagi penduduknya (Kementan, 2011). Ketergantungan Indonesia terhadap impor sejumlah komoditas pangan merupakan salah satu penyebab ancaman krisis pangan di negara kita. Disamping itu tingkat pertumbuhan penduduk Indonesia yang mencapai 1,49\% (BPS, 2011).

Menurut Irawan dan Nana (2011), sorgum merupakan bahan pangan lokal dan pengembangannya memiliki potensi untuk mendukung program pemerintah dalam upaya penyediaan pangan dan diversifikasi pangan serta dapat mengurangi ketergantungan tepung terigu yang selama ini dipenuhi melalui impor. Biji sorgum memiliki kandungan gizi yang baik, seperti karbohidrat, protein, lemak, mineral, dan vitamin, serta tidak mengandung gluten seperti yang terdapat di dalam gandum, sehingga aman untuk penderita penyakit intoleran terhadap gluten seperti autisme, penyakit seliak, dan lainsebagainya (Mardawati et al., 2010).

Masalah utama penggunaan biji sorgum sebagai bahan pangan maupun pakan adalah kandungan tanin yang dapat mempengaruhi kegunaan protein serta fungsi asam-asam aminonya. Tanin dalam biji sorgum berkisar antara $0,10-3,60 \%$ yang sebagian besar terletak pada testa. Tanin pada biji sorgum dapat menjadi zat antinutrisi dan dapat menimbulkan rasa pahit pada produk yang dihasilkan Selain itu pengupasan biji sorgum relatif cukup sulit 3 dilaksanakan dan memerlukan desain alat khusus. Tanin, metabolit sekunder yang ditemukan di banyak spesies tumbuhan, merupakan senyawa fenolik yang sering berperan sebagai mekanisme pertahanan melawan patogen dan predator (Kaufman et al., 2013).
Sorgum merupakan sumber mineral (fosfor, kalium, dan seng) yang kandungannya bervariasi sesuai dengan tempat budidaya (Martino et al., 2012 ; Shegro et al., 2012 ; Silva et al., 2012). Ketersediaan hayati dari sebagian besar mineral sorgum masih sedikit diketahui. Namun, diketahui bahwa ketersediaan seng bervariasi antara 9,7\% dan $17,1 \%$. dan ketersediaan zat besi berkisar dari 6,6\% hingga 15,7\% (Afify et al., 2011; Kruger et al., 2013). Studi telah dilakukan secara berurutan untuk meningkatkan kandungan dan bioavailabilitas zat besi dan seng melalui biofortifikasi, fortifikasi, dan perbaikan genetik sorgum (Ashok Kumar et al., 2013; Kruger et al., 2013; Tripathi dan Platel, 2013).

Informasi tentang kandungan vitamin dalam sorgum masih langka. Namun, perlu dicatat bahwa ini adalah sumber dari beberapa B-kompleks vitamin (tiamin, riboflavin, dan piridoksin) dan larut dalam lemak vitamin (D, E, dan K) (Ochanda et al., 2010; Martino et al., 2012 ; Cardoso et al., 2014). Komoditas sayuran sangat layak untuk dipertimbangkan dalam menunjang program diversifikasi pangan. Mengingat, Indonesia sudah lama menerapkan sistem diversifikasi pangan. Pemerintah sendiri sudah menyadari pentingnya dilakukan diversifikasi pangan, karena program tersebut dapat meningkatkan mutu gizi makanan yang dikonsumsi sehingga dapat meningkatkan status gizi masyarakat (Almatsier, 2011).

Salah satu sayuran yang mempunyai potensi untuk dikembangkan di Indonesia adalah bit. Buah bit mengandung vitamin $\mathrm{C}$ yang cukup tinggi sehingga dapat digunakan sebagai antioksidan yang dapat mencegah penyakit kanker. Selain antioksidan, buah bit juga memiliki komponen utama yaitu pigmen betasianin yang memberikan warna merah keunguan (Wibiwanto, 2014). Beberapa nutrisi yang terkandung dalam umbi bit yaitu, karbohidrat, protein, serat, berbagai mineral serta kadar air yang tinggi,vitamin A, vitamin C, kalsium zat besi, fosfor, protein dan karbohidrat. Selama ini pigmen betasianin banyak digunakan sebagai pewarna makanan. Sehingga perlu dilakukan pemanfaatan 
pigmen betasianin yang lebih luas yaitu sebagai pewarna alami dalam sediaan farmasi. Secara umum, pewarna alami kurang stabil terhadap cahaya, panas, dan pada nilai $\mathrm{pH}$ tertentu dibandingkan dengan pewarna sintesis (Allam dan Kumar, 2011).

zat warna yang berasal dari umbi itu merah dikategorikan sebagai nondyestuff (bukan bahan pewarna sintetik) dan tidak ada batasan konsumsi menurut rekomendasi EFC (mg/kg berat badan) sehingga tidak ada akumulasi maksimal zat warna tersebut di dalam tubuh Betasianin adalah salah satu pewarna alami penting yang banyak digunakan dalam sistem pangan. Walaupun pigmen betasianin telah digunakan untuk pewarna alami sejak dahulu tetapi pengembangannya tidak secepat antosianin. Hal ini karena keterbatasan tanaman yang mengandung pigmen betasianin. Sampai saat ini pigmen betasianin yang telah diproduksi dalam skala besar hanya berasal dari buah bit (Beta vulgaris L). Betasianin dari buah bit telah diketahui memiliki efek antiradikal dan aktivitas antioksidan yang tinggi (Mastuti ,2010).

Betasianin adalah zat warna yang berfungsi memberikan warna merah dan berpotensi menjadi pewarna alami untuk bahan pangan yang lebih aman bagi kesehatan dibanding pewarna sintetik (wibawanti et al., 2014).Antioksidan adalah senyawa yang membantu menetralkan masuknya radikal bebas yang berbahaya di dalam tubuh. Antioksidan juga bisa mencegah terjadinya stres oksidatif dan merusak sel-sel baik di dalam tubuh Anda. Selain itu beberapa penelitian telah menemukan bahwa antioksidan dapat melindungi tubuh terhadap banyak jenis penyakit kronis, seperti penyakit jantung, kanker dan diabetes. Manfaat buah bit secara alami juga terdapat pada tingginya kandungan fitonutrien untuk melawan penyakit, antioksidan, vitamin dan mineral. Bahkan, buah bit dianggap menjadi salah satu sumber buah yang mengandung jenis fitonutrien, yakni, betalain. Betalain baik untuk mencerahkan warna kulit. Ia juga mampu membantu melindungi beberapa perkembangan jenis kanker dan penyakit lainnya di tubuh Anda. Salah satu cara pemanfaatan buah bit adalah dengan diolah menjadi tepung buah bit. Antioksidan adalah senyawa yang membantu menetralkan masuknya radikal bebas yang berbahaya di dalam tubuh. Antioksidan juga bisa mencegah terjadinya stres oksidatif dan merusak sel-sel baik di dalam tubuh Anda. Selain itu beberapa penelitian telah menemukan bahwa antioksidan dapat melindungi tubuh terhadap banyak jenis penyakit kronis, seperti penyakit jantung, kanker dan diabetes. Manfaat buah bit secara alami juga terdapat pada tingginya kandungan fitonutrien untuk melawan penyakit, antioksidan, vitamin dan mineral. Bahkan, buah bit dianggap menjadi salah satu sumber buah yang mengandung jenis fitonutrien, yakni, betalain.

Betalain baik untuk mencerahkan warna kulit. Ia juga mampu membantu melindungi beberapa perkembangan jenis kanker dan penyakit lainnya di tubuh Anda. Salah satu cara pemanfaatan buah bit adalah dengan diolah menjadi tepung buah bit. Flake cereal umumnya dibuat dengan menggunakan gandum, beras (utuh atau pecah) atau jagung (utuh atau grits). Tekstur serealia menjadi faktor yang perlu dipertimbangkan agar dapat diperoleh flake dengan tekstur yang renyah. Jika menggunakan gandum, maka lebih disukai untuk menggunakan varietas gandum lunak (kadar gluten rendah). Warna sereal bukan menjadi faktor pertimbangan karena proses produksi flaked cereal biasanya melibatkan panas yang akan menghasilkan produk yang berwarna kecoklatan (Hiemori et al., 2009).

Flake merupakan salah satu jenis sereal sarapan ready to eat dengan kadar air rendah dan tekstur renyah. Proses pembuatan flake sangat sederhana yaitu melalui tahap perebusan, pemipihan dan pengeringan Flakes juga merupakan produk pangan yang termasuk ke dalam kategori makanan sereal siap saji atau RTE (Ready-to-eat) yang telah dilakukan pengolahan dan rekayasa sesuai dengan jenis dan bentuknya. Banyak flake 
adalah makanan kering yang mengandung protein, lemak, sakarida beserta mineral dan vitamin. Flakes gandum telah paling luas dipelajari sebagai sumber serat, juga barubaru ini sebagai sumber polifenol dan flavonoid. Penelitian ini bertujuan untuk 1) Mengetahui pengaruh penambahan tepung sorgum pada adonan flakes, 2) Mengetahui pengaruh penambahan tepung bit root pada adoanan flakes, 3) Mengetahui pengaruh penambahan tepung sorgum dan bit root dengan berbeda perlakuan untuk menghasilkan flakes terbaik terhadap sifat kimia (antioksidan), fisik (kerenyahan) dan sifat organoleptik

\section{METODE}

\section{Bahan}

Bahan yang di gunakan dalam pembuatan flakes sorgum dan bit root adalah tepung sorgum, tepung bit root, garam, gula, air

\section{Alat}

Alat yang di gunakan dalam pembuatan flakes sorgum dan bit root adalah timbangan digital, saringan plastik, sendok alumunium, gelas ukur, kompor (rinnai), panci, baskom, piring, plastik segitiga,oven.

Alat yang di gunakan dalam analisa fisika kimia adalah gelas (pyrex), mikropipet,oven, timbangan analitik,cawan porslen, desikator,penjepit krus

\section{Metode/pelaksanaan}

Penelitian dilakukan di laboratorium Ilmu dan Teknologi Pangan Universitas Yudharta Pasuruan pada bulan April - Juli 2020.

Metode yang digunakan dalam penelitian ini adalah Rancangan Acak Lengkap (RAL) dengan 2 faktor. Faktor pertama yaitu penambahn tepung sorgum (30 gr, 60gr, 90gr), faktor ke dua yaitu penambahan tepung bit root (5gr, 10gr, 15gr). Terdapat 9 kombinasi perlakuan dan masing masing perlakuan dilakukan 3 kali pengulangan. Data yang diperoleh dari hasil penelitian dianalisis secara deskriptif dari data rata-rata ulangan setiap parameter. Perlakuan terbaik dipilih berdasarkan hasil uji sesuai parameter pengujian. Data pengamatan hasil analisa kimia dilakukan pengolahan data dengan analisa variansi (anova) pada taraf perbedaan $5 \%(\alpha=0,05)$. Parameter yang dianalisa yaitu Kadar Air. Analisis organoleptik dilakukan tehadap rasa, aroma, warna dan tekstur pada masingmasing perlakukan menggunakan metode Hedonic Test dengan skala nilai 1-5. Semakin tinggi nilai yang diberikan maka semakin tinggi pula tingkat kesukaan konsumen.

Hasil dari pengujian organoleptik oleh para panelis dianalisa dengan uji Friedman pada taraf signifikansi $5 \%$ untuk mengetahui adanya perbedaan antara sampel. Untuk menentukan kombinasi perlakuan terbaik dilakukan dengan uji Efektifitas sehingga bisa diketahui kombinasi perlakuan terbaik sesuai preferensi panelis.

Pembuatan Flake sorgum yaitu dengan penambahan tepung sorgum dantepung bit root yang di beli di toko online shopie semua bahan di campurkan dan di beri tambahan gula sekitar 20gr yang telah di larutkan dalam air kemudian di campurkan dengan tepung sorgum dan tepung bit yang sudah di timbang sebelumnya sesuai perlakuan kemudian proses pencampuran kedua bahan dengan 100ml airyang sudah tercampur garamsetelah itu adonan di masukkan ke dalam plastik segitiga untuk kemudian di cetak pada loyang kemudian adonan yang telah di cetak akan di masukkan ke dalam oven dengan suhu 130-150 derajat celcius dengan lama waktu yaitu 15-30 menit setelah selesai flakes di angkat dan di sajikan. 
Proses Pengolahan Flakes Sorgum

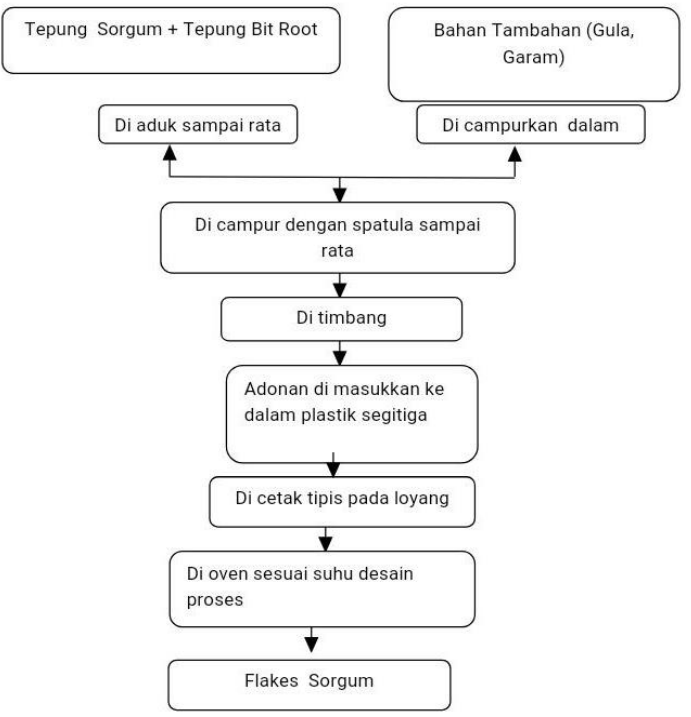

Gambar 1. Diagram alir pengolahan flake sorgum

\section{HASIL DAN PEMBAHASAN}

Pada sifat bahannya. Pada umumnya penentuan kadar air dilakukan dengan mengeringkan bahan dalam oven pada suhu $105-110{ }^{\circ} \mathrm{C}$ selama $15-30$ menit atau sampai didapat berat yang konstan.

Kadar air pada sampel S2B2 dan S3B3 menunjukkan hasil yang berbeda nyata.Hal ini dikarenakan pengaruh serat pangan didalamnya. Menurut Mulyani (2013) serat memiliki kemampuan mengikat air, air yang terikat kuat dalam serat pangan sulit untuk diuapkan kembali walaupun dengan proses pengeringan. Semakin tinggi konsentrasi pati maka kadar air produk semakin tinggi. Hal tersebut terjadi karena semakin tinggi pati, maka partikel bahan lebih padat, sehingga kemampuan panas pengeringan lebih rendah (Richana, 2010).. Pengujian kadar air dilakukan pada flake sorgum dapat di lihat pada diagram 2.

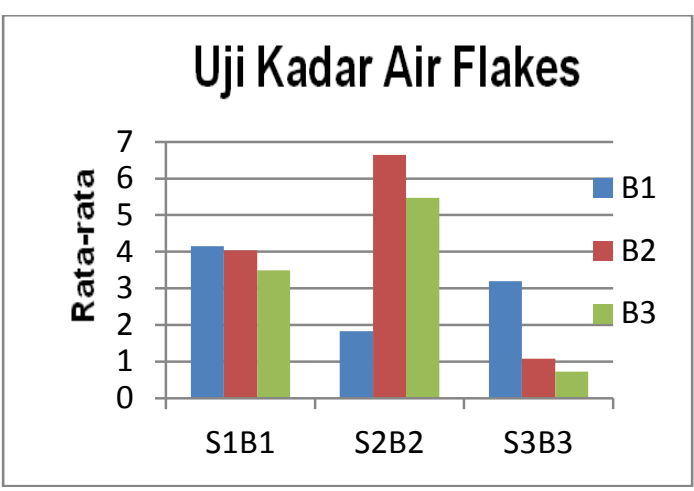

Gambar 2. Diagram uji kadar air

Menurut SNI-2886- 2000 , kadar air maksimal untuk susu seral yaitu 4\%. Dari hasil pengamatan terhadap Flakes sorgum dengan tiga kali pengulangan dapat dilihat bahwa semakin banyak tepung sorgum yang di tambahkan, maka kandungan air yang di hasilkan akan semakin kecil hal ini di karenakan tepung sorgum dapat menyerap air dan membuat adonan yang terlalu banyak.

menggunakan tepung sorgum akan sedikit kering dapat di lihat dari diagram hasil penelitian kadar air yang paling kecil yaitu pada perlakuan S3B3 dengan nilai 0,723 dengan formulasi $90 \mathrm{gr}$ tepung sorgum dan $15 \mathrm{gr}$ tepung bit dan tertinggi pada perlakuan S2B2 demgan nilai 6,641 dengan formulasi $60 \mathrm{gr}$ tepung sorgum dan 10gr tepung bit root.

\section{Uji organoleptik}

Pengujian organoleptik dilakukan melalui uji hedonik dengan 25 orang panelis tidak terlatih meliputi rasa, aroma warna dan tekstur dari Flake sorgum, dengan skala penilaian $1-5$ yaitu (1) tidak suka, (2) kurang suka, (3) biasa, (4) suka, dan (5) sangat suka. Hasil uji organoleptik warna Flake menunjukkan sampel yang lebih disukai hal ini di karenakan kandungan antosianin yang terkandung dalam bit root yang memberikan warna merah keunguan sangat di sukai panelis. 


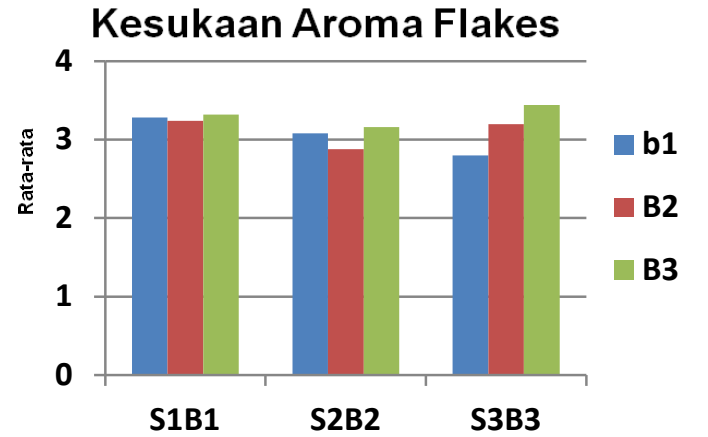

Gambar 3. Diagram kesukaan aroma flake sorgum

Dari hasil pengamatan uji organoleptik pada aroma Flakes dapat di lihat nilai tertinggi yaitu pada perlakuan S3B3 dengan nilai 6,40 dengan formulasi tepung sorgum 90 gr dan tepung bit root $15 \mathrm{gr}$ hal ini di karenakan semakin banyak tepung sorgum yang di tambahkan maka akan semakin tercium aroma flakes. Sedangkan nilai terendah pada yaitu pada perlakuan S3B1dengan nilai 3,70 dengan formulasi $90 \mathrm{gr}$ tepung sorgum dan $5 \mathrm{gr}$ tepung bit root,aroma pada formulasi ini tidak di sukai panelis karena tepung bit root terlalu sedikit yaitu $5 \mathrm{gr}$, jadi tepung sorgum dan tepung bit root sangat perpengruh terhadap aroma flakes.

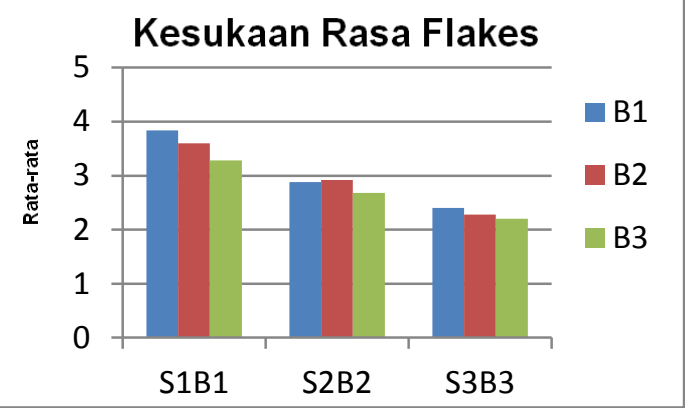

Gambar 4. Diagram kesukaan rasa flake sorgum

Tingkat kesukaan rasa terhadap Flakes sorgum di dapat penilaian terbaik yaitu S1B1 dengan formulasi $30 \mathrm{gr}$ tepung sorgum dan $5 \mathrm{gr}$ tepung bit root dengan nilai 7,38 hal ini di karenakan penambahan tepung yang sedikit yaitu 30gr sorgum dan penambahn gula 20gr per adonan jadi semakin sedikit tepung yang di tambahkan maka akan semakin terasa rasa manis pada flakes, sedangkan nilai terendah yaitu pada perlakuan S3B3 dengan nilai 2,88dengan formulasi $90 \mathrm{gr}$ tepung sorgum dan $15 \mathrm{gr}$ tepung bit root rasa pada perlakuan ini sangat hambar karena penambahan tepung sorgum yang banyak mengakibatkan rasa manis gula pada flakes dengan perlakuan ini tidak terasa.

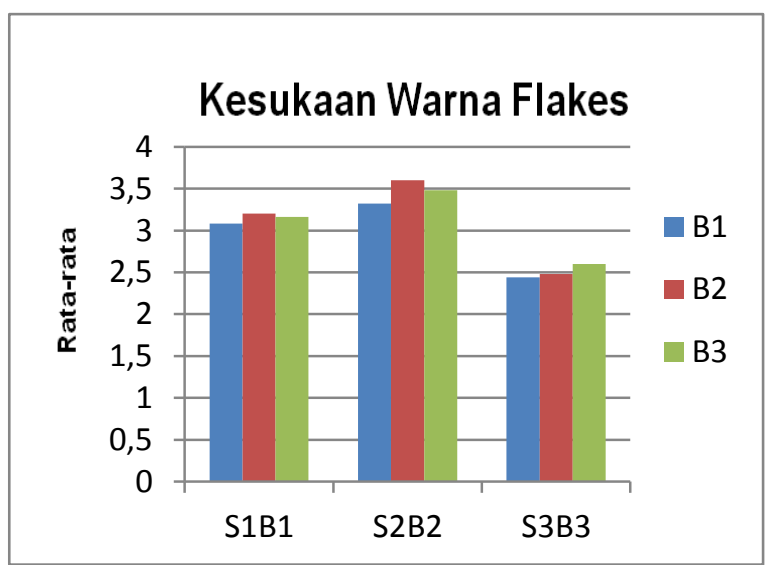

Gambar 5. Diagram kesukaan warna flake sorgum

Penilaian panelis terhadap warna flakes menunjukkan warna flakes perlakuan S2B2 dengan nilai 6,32 dengan formulasi $60 \mathrm{gr}$ tepung sorgum dan $10 \mathrm{gr}$ tepung bit lebih di sukai hal ini di karenakan Komponen utama yang terdapat dalam umbi bit yaitu pigmen betasianin yang berwarna merah keunguan, yang berpotensi sebagai zat warna alami (Wibawanto et al., 2014). dan juga dengan takaran yang tepat yaitu 60gr tepung sorgum dam 10 gr tepung bit root sehingga warna tidak terlalu mencolok dan juga tidak terlalu pucat kemudian war na S3B1 lebih tidak di sukai. Karna warna terlalu puyeh di karenakan penambahn tepung sorgum yang banyak yaiti $90 \mathrm{gr}$.

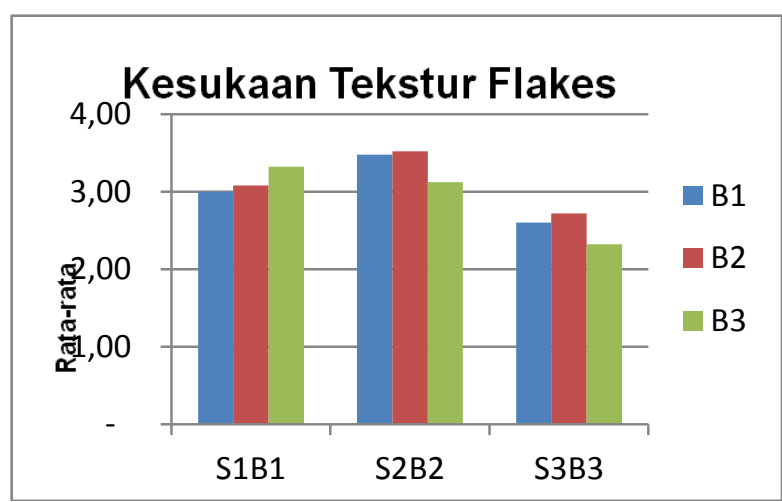

Gambar 5. Diagram kesukaan Tekstur Flake sorgum 
Penilaian panelis terhadap tekstur flakes sorgum menunjukkan perlakuan terbaik pada S2B2 dengan nilai 6,40 dengan formulasi $60 \mathrm{gr}$ tepung sorgum dan $10 \mathrm{gr}$ tepung bit root hal ini karenakan penambahan air pada adonan yaitu $100 \mathrm{ml}$ per adonan dan juga di pengaruhi oleh penambahan tepung sorgum ,semakin sedikit tepung sorgum yang di tambahkan maka adonan akan terasa encer dan susah di cetak hal ini juga mempengaruhi hasil pada flakes ,flakes yang di hasilkan akan mudah patah, dan nilai terendah pada perlakuan S3B3 dengan nilai 3,70 dengan penambahn tepung sorgum $90 \mathrm{gr}$ dan tepung bit root $15 \mathrm{gr}$ semakin banyak tepung sorgum yang di tambahkan maka adonan akan semakin kesat dan tekstur flakes akan mudah hancur karena partikel tepung tidak terikat oleh air dengan baik hal ini juga akan berpengaruh pada flakes yang di hasilkan, flakes akan mudah hancur.

Dari hasil pengolahan data organoleptik diperoleh $X_{\text {hitung untuk }}$ parameter rasa sebesar 55,29 warna sebesar 19,29, Tekstur sebesar 34,31 dan aroma sebesar 14,05. Nilai $X_{\text {hitung }}$ dari ketiga parameter rasa, warna maupun aroma lebih besar dari nilai $X_{\text {tabel }}$ kecuali aroma bisa disimpulkan ada perbedaan signifikan dalam hal rasa, tekstur dan warna dan tidak ada perbedaan signifikan pada aroma dari 9 perlakuan Flakes sorgum yang diujikan.

\section{Uji efektifitas}

Dari hasil uji efektifitas dapat disimpulkan bahwa perlakuan Flakes sorgum yang paling disukai adalah dengan formulasi tepung sorgm $60 \mathrm{gr}$ dan bit10gr dengan hasil indeks tertinggi sebesar 1,072. Dibandingkan perlakuan yang lain, Hal ini dipengaruhi oleh preferensi panelis yang lebih memberikan pembobotan untuk parameter tekstur dan warna dibandingkan aroma dan rasa, sehingga meskipun flakes sorgum kurang disukai rasa dan aromanya namun dari visual warna dan tekstur menunjukkan flakes sorgum lebih dipilih.

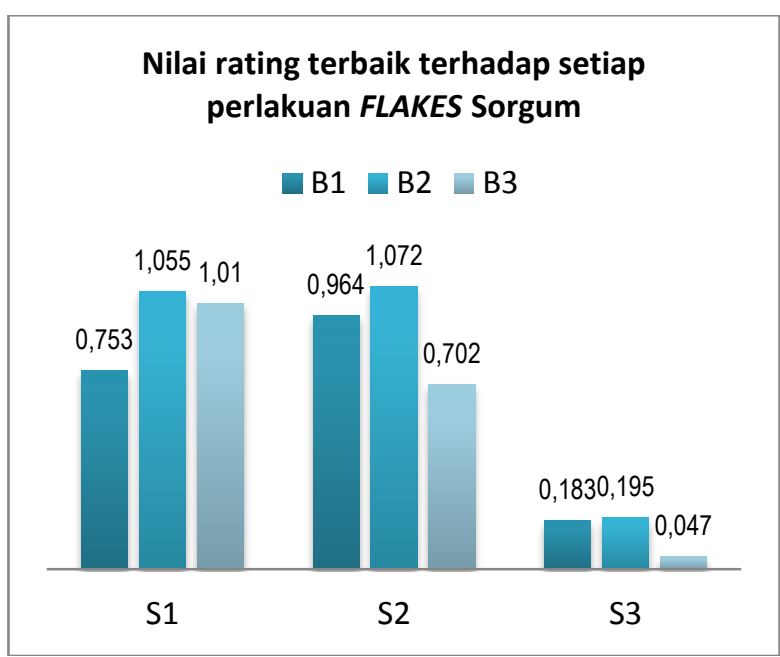

Gambar 3. Perlakuan terbaik flake sorgum

\section{KESIMPULAN}

Dari hasil penelitian yang telah dilakukan dapat disimpulkan bahwa

1. Penambahan tepung sorgum dan tepung bit root paada setiap perlakuan berpengaruh adonan flake semakin banyak tepung sorgum yang di tambahkan maka akan semakin keras adonan dan juga akan menghasilkan flake yang mudah hancur begitupula pada adonan flake yang terlalu sedikit akan mengakibatkan adonan menjadi encer dan susah untuk di bentuk dan akan menghasilkan flake yang mudah patah dan juga berpengaruh pada tekstur flakes ,warna,dan aroma pada flakes yang di hasilkan

2. Semakin tinggi kadar air maka akan berpengaruh terhadap tekstur flakes dan juga memperpendek daya simpan flakes karena bahan yang lembab akan mudah terpapar mikroba dan jamur

3 Kombinasi perlakuan terbaik untuk pembuatan Flake sorgum adalah dengan menggunakan tepung sorgum 60gr dengan penambahan tepung bit $10 \mathrm{gr}$.

\section{DAFTAR PUSTAKA}

Afify, A. E.-M.M. R., El-Beltagi,H. S., Abd El-Salam, S.M. \& Omran, A. A. (2011). Bioavailability of iron, zinc, phytate and phytase activity during soaking and germination of white 
sorghum varieties. Journal Pone, 6(10),

http://dx.doi.org/10.1080/10408398.20 14.887057

Allam, K. V, \& Kumar, G. P. (2011). Colorants-the cosmetics for the pharmaceutical dosage forms. International Journal of Pharmacy and Pharmaceutical Sciences, 3(3), 13-21.

Almatsier, S. (2011). Gizi Seimbang dalam Daur Kehidupan. Jakarta: Gramedia Pustaka Utama.

Andarwulan N, Batari R, Sandrasari D A, Bolling B, Wijaya H (2010). Short communication flavonoid content and antioxidant activity of vegetables from Indonesia. Journal of Food Chemistry; 121(4), 1231-1235

Ashok Kumar, A., Reddy, B. V. S., Ramaiah, B., Sahrawat, K. L. \& Pfeiffer, W. H. (2013). Gene effects and heterosis for grain iron and zinc concentration in sorghum [Sorghum bicolor (L.) Moench]. Field Crop. Journal of SAT Agricultural Research. 11(3), 86-95.

BSN. (2000). Badan Standarisasi Nasional. 2000. Syarat Mutu Sereal (SNI 014270-1996). Badan Standarisasi Nasional. Jakarta.

Cardoso, L. d. M., Montini, T. A., Pinheiro, S. S., Pinheiro Sant'Ana, H. M., Martino, H. S. D. \& Moreira, A. V. B. (2014). Effects of processing with dry heat and wet heat on the antioxidant profile of sorghum (Sorghum bicolor L.). Food Chem. Journal of Food Chemistry 152, 201-217. https://doi.org/10.1016/j.foodchem.201 6.11 .065

Darwin, P. 2013. Menikmati Gula Tanpa Rasa Takut. Yogyakarta: Sinar Ilmu.

Faizah, S.N. (2014). Hubungan antara kebiasaan sarapan pagi dan kebiasaan jajan terhadap prestasi belajar siswa Sekolah Dasar SDN Banyuanyar III Surakarta. Jurnal kesehatan masyarakat unai, 3 (1), 203-207

Gunawan, G. A., Atmodjo, P. K., \& Sidharta, B. B. R. (2013). Variasi Kismis dan Sukrosa Terhadap Pertumbuhan Asam
Laktat dan Alkohol Kristal alga. Jurnal Teknologi Pangan, 1-14.

Hiemori, M., E. Koh \& A.E. Mitchell. (2009). Influence of Cooking on Anthocyanins in Black Rice (Oryza sativa L. japonica var SBR). Journal of Agricurtural and Food. Chemistry., 57 (5), 1908-1914.

Irawan Bambang \& Sutrisna Nana (2011). Prospek pengembangan sorgum di Jawa Barat mendukung diversivikasi pangn ,Pusat sosial ekonomi dan kebijakan pertanian, jurnal forum penelitian agro ekonomi. 29 (2), 99113

Kaufman, R. C., Herald, T. J., Bean, S. R., Wilson, J. D. \& Tuinstra, M. R. (2013). Variability in tannin content, chemistry and activity in a diverse group of tannin containing sorghum cultivars. Journal of Science Food Agriculture. 93 (5), 1233-1241.

Kruger, J., Taylor, J. R. N., Du, X., De Moura, F. F., L€onnerdal, B. \& Oelofse, A. (2013). Effect of phytate reduction of sorghum, through genetic modification, on iron and zinc availability as assessed by an in vitro dialysability bioaccessibility assay, Caco-2 cell uptake assay, and suckling rat pup absorption model. Journal of Food Chem. 141, 1019-1025.

Martino, H. S. D., Tomaz, P. A., Moraes, E.

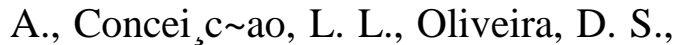
Queiroz, V. A. V., Rodrigues, J. A. S., Pirozi, M. R., Pinheiro-Sant'Ana, H. M. \& Ribeiro, M. R. (2012). Chemical characterization and size distribution of sorghum genotypes for human consumption. Rev. Inst. Adolfo. Lutz. Journal of Documentos / Embrapa Milho e Sorgo, 170, 337-344.

Mardawati, E., Sukarminah, E., Onggo, T.M. Tjahjadi, C. \& Indiarto, R. (2010). Pengolahan Biji Sorgum Menjadi Aneka Produk Pangan. Pustaka Giratuna. Bandung. jurnal unpad Chimica et Natura Acta. 6 (2), 74-78 https://doi.org/10.24198/cna.v6.n2.184 81 
Mulono, A., \& Rujiah. (2017). Kimia pangan (M. N. Rohman, Ed.). Yogyakarta: Tussmedia Grafika

Mulyani Anny \& Sarwani Muhrizal. (2013). Karakteristik dan Potensi Lahan Sub Optimal untuk Pengembangan Pertanian di Indonesia. Jurnal sumber daya lahan. 7 (1), 47-55

Ochanda, S. O., Onyango, C., Mwasaru, A., Ochieng, J. \& Mathooko, F. (2010). Effects of malting and fermentation treatments on group Bvitamins of red sorghum, white sorghum and pearl millets in Kenya. Journal of Applied Biosciences 34, 2128 - 2134.

Richana, N, F. Nursyarifa, Pujoyuwono dan H. Herawati. (2010). Optimasi Proses Produksi Maltodextrin dari Tapioka Menggunakan Spray Dryer. Balai Besar dan Pengembangan Pascapanen Pertanian. [skripsi]. Jurusan Teknologi Pangan. Universitas Pasundan. Bandung.

Setiaji, Pratomo. (2012). "Sistem Pendukung Keputusan Dengan MetodeSimple Additive Weighting". [skripsi]. Jurusan Sistem Informasi, Teknik. Universitas Muria Kudus..

Setiawan, W. A. M., Nugroho, K. E., \& Lestario, N. L. (2015). Ekstraksi betasianin dari kulit umbi bit (Beta vulgaris L.) sebagai pewarna alami. Jurnal Ilmu Pertanian, 27(1), 38-43. https://doi.org/https://doi.org/10.24246/ agric.2015.v27.i1.p38-43

Shegro, A., Shargie, N. G., van Biljon, A., \& Labuschagne, M. T. (2012). Diversity in starch, protein and mineral composition of sorghum landrace accessions from Ethiopia. Journal of Crop Science and Biotechnology,13 (2), $67-74$ https://doi.org/10.3923/jbs.2013.67.74

Taylor, J. R. N. \& Emmambux, M. (2010). Developments in our understanding of sorghum polysaccharides and their health benefits.journal of Cereal chemistry. 87 (4), 263-271.
Tripathi, B. \& Platel, K. (2013). Feasibility in fortification of sorghum (Sorghum bicolor L. Moench) and pearl millet (Pennisetum glaucum) flour with iron. Journal of Food Science Technology science. $\quad 50(1), \quad 220-225$. https://doi.org. 10.1016/j.lwt.2012.05.0 25

Wibawanto, N. R., Victoria, K. A., \& Rika, P. (2014). Produksi Serbuk Pewarna Alami Bit Merah (Beta vulgaris L.) dengan Metode Oven Drying. Jurnal Fakultas Teknik Univesitas Wahid Hasyim Semarang, 1(1), 38-43.

Wirakusumah, E.S. (2007). 202 Jus Buah dan Sayur. Jakarta : Penebar Plus. 